\title{
International Consumer Law: What Is It All About?
}

\section{Durovic ${ }^{1}$ (iD}

Received: 4 July 2019 / Accepted: 16 October 2019 / Published online: 21 December 2019

(C) The Author(s) 2019

\begin{abstract}
Increasing effort has been invested in the internationalization of consumer law. Some of the recent huge global consumer law-related scandals (e.g., Dieselgate, Facebook) demonstrate the rising relevance of and the need for international consumer law. This paper argues that the efforts towards the internationalization of consumer law should focus, first, on the establishment of globally accepted minimum standards of consumer protection (as it has been done through the United Nations Guidelines on Consumer Protection) and, second, on the development and facilitation of cooperation as a necessary prerequisite for the efficient protection of consumers (as it has been initiated by the International Consumer Protection and Enforcement Network), rather than on the harmonization of substantive consumer law. This is not only because coordination among diverse countries in the area of consumer protection is easier to achieve in practice through a policy approach rather than substantive harmonization, but also because coordination in practice is an instrument that, as it stands now, is capable of providing a higher level of protection to consumers than substantive harmonization.
\end{abstract}

Keywords Internationalization - United Nations Guidelines for Consumer Protection · ICPEN · International consumer law

In an increasingly globalized world with a profoundly internationalized market, law remains one of the least globalized elements of the society. However, even law is becoming more and more internationalized, crossing the borders of national jurisdictions. That is also the case with consumer law, where there is a noticeable tendency to develop supranational rules, or, at least, internationally recognized principles of consumer law (Durovic and Micklitz 2017).

In their editorial note to one of the issues of the Journal of Consumer Policy in 2010, Christian Twigg-Flesner and Hans Micklitz observed that there is a lack of "[a] consistent attempt to consider the international implications of consumer law and policy" (Twigg-Flesner

M. Durovic

Mateja.durovic@kcl.ac.uk

1 Dickson Poon School of Law, King's College London, England, UK 
and Micklitz 2010, p. 201). Ten years later, this statement still seems to hold true. International consumer law has been under-studied and its potential has not yet been examined sufficiently.

Some of the recent major global consumer law scandals which simultaneously affected consumers in many different jurisdictions (e.g., Apple ${ }^{1}$ or Dieselgate ${ }^{2}$ ) have demonstrated the increasing relevance of international consumer law, highlighting the need for a response to these consumer law issues on a global level. This is even more so especially when it comes to the enforcement of consumer law rules. Moreover, the recent substantial modifications and further developments of the UN Guidelines for Consumer Protection (hereinafter "UN Guidelines") and subsequent related global activities in the area of consumer protection have called for more examination in the area (United Nations 2016).

Therefore, this paper aims to contribute to scholarship in this area by examining critically the phenomenon of the internationalization of consumer law, and by proposing directions for the future development of international consumer law. The main argument put forward in this paper is that the efforts towards the internationalization of consumer law need a sharper focus on, first, the establishment of globally accepted minimum standards of consumer protection and, second, the development and facilitation of cooperation as a necessary pre-requisite for the efficient protection of consumers rather than on the harmonization of substantive consumer law. In line with its principal objective, the analysis of this paper will focus, first, on the UN Guidelines as the most important source of international consumer law and, second, on the International Consumer Protection and Enforcement Network (ICPEN) as the most prominent global framework for cooperation in the area of consumer protection.

\section{The Two Principal Functions of International Consumer Law}

Consumer law is a relatively young legal discipline (Ramsay 2007). Traditionally, 1962 is taken as the year of birth of modern consumer law and policy. This is the year when US President John F. Kennedy gave his famous speech in which he set the foundations for the subsequent development of a regulatory framework exclusively dedicated at protection of consumers not only in the USA, but also worldwide. ${ }^{3}$ Eventually, the development of a new regulatory framework for the protection of consumers led to the establishment of a new legal discipline: consumer law. Over the course of the intervening fifty-eight years, consumer law has developed into a separate area of law which has spread, in diverse manners and to different extents, throughout the entire world. The European Union has provided an especially fertile ground for the flourishing of consumer law, and the EU has developed the most advanced regulatory regime for consumer protection globally (Stuyck 2000).

Concurrently with this development of national consumer protection law, attempts have been made to internationalize consumer law. The internationalization of consumer law was intended to achieve two main goals: (1) the establishment of a universally applicable minimum standard of consumer protection, and; (2) the abolition of obstacles for the development of cross-border trade. Distinguishing between these two goals may be very important as they

\footnotetext{
${ }^{1}$ See Durovic, M. (2016). The Apple case today: Factual and legal assessment. EUI Department of Law Research Paper No. 2016/03. Retrieved from https://doi.org/10.2139/ssrn.2736380 (accessed 7 October 2019).

2 See Nemeth. K. and Carvalho, J. (2017). "Dieselgate" and consumer law: Repercussions of the Volkswagen scandal in the European Union. Journal of European Consumer and Market Law 6(1), 253.

${ }^{3}$ Kennedy, J. F. (1962). Special Message on Protecting the Consumer Interest. Retrieved from https://www. presidency.ucsb.edu (accessed 25 June 2019).
} 
reflect the dual nature of the internationalization of consumer law. The double nature of the international consumer law also demonstrates the tension between, on the one side, the urge to establish global minimum standards of consumer protection and, on the other side, the need for the abolition of cross-border differences in order to enhance international trade.

Accordingly, the first aim of the internationalization of consumer law is to lay down a "floor" benchmark for consumer protection, which is accepted in every jurisdiction. International benchmarking in consumer law is increasingly built into the work of regulators and policymakers. Benchmarking may have a significant impact on consumer policy globally (Ramsay 2006, p. 16). In that sense, international consumer law may be understood as the emanation of the evolution of human civilization, where the right to be protected while acting as a consumer has become one of the fundamental human rights, which is something especially important in the contemporary world and its economic model based on consumption. In that context, the principal objective of international consumer law is to establish a minimum level of consumer protection on a global level that would surpass any national border (Ramsay 2006). Today, the question of consumer protection has become an issue of democracy and basic democratic values of any society, and the development of consumer law may be seen as part of the democratization process of the countries, nations and societies. Every citizen is also ipso facto a consumer. As famously stated at the very beginning of the development of consumer law by President Kennedy: "Consumers, by definition, include us all.",

The focus of this category of rules of international consumer law is the protection of consumers, i.e., the development of rules which are going to protect the consumers from potential abuse by traders due to the presence of an inequality of bargaining powers irrespective of where consumer or trader are based. The objective of this approach is to stipulate basics rules only, and it has been left to national legal systems to develop and implement comprehensive and well-functioning national consumer protection systems in line with their needs and particularities. In the context of this first aim, the main driving force behind the development of this kind of rules has been the United Nations and, in particular the United Nations Conference for Trade and Development (UNCTAD). On a global scale, the main vehicle for pursuing the internationalization of consumer law remains the UN Guidelines for Consumer Protection. However, UNCTAD's powers when it comes to enforcement of consumer law have been very limited. In that light, the existence and the recent developments of the ICPEN network can be appreciated as a very significant development, because it aims to secure some minimum level of enforcement of consumer law on a global level.

The internationalization of the market has also contributed to the development of certain traders as global players. For example, today one of the biggest global companies is Amazon. It first started as an online bookstore, but it quickly expanded to all sorts of consumer products, such as electronics, fashion and home goods. Amazon ships products offered on its website in 300 jurisdictions $^{5}$ on all continents. ${ }^{6}$ Such an internationalization of consumer transactions also requires an adequate "international" regulatory response from consumer law. In this sense, the major objective of the international consumer law has to be the maintenance of a minimum

\footnotetext{
${ }^{4}$ Ibid.

${ }^{5}$ Many countries around the globe sub-divided into multiple jurisdictions, hence the large number.

${ }^{6}$ Retrieved from https://www.amazon.com/gp/help/customer/display.html?nodeId=201910800 (accessed 25 June 2019).
} 
level of consumer protection below which no jurisdiction should go. Technological developments and their potential benefits the society must never be used as an excuse to diminish the level of consumer protection.

The second goal motivating the development of a uniform international consumer law is the eradication of barriers to cross-border trade. A divergence in consumer protection regimes could be seen as an inhibition to trade; in fact, the World Trade Organization sees distinct consumer law rules in a jurisdiction as a "non-tariff obstacle to the development of crossborder trade" (Grainger 2011, pp. 53-54). The goal of international consumer law here is primarily the establishment of equal standards in the regulatory frameworks of consumer protection in order to enhance the performance of cross-border consumer transactions. The focus of the internationalization of the rules here is evidently not on protection of consumers, but rather on the facilitation of compliance requirements for traders willing to trade regionally or globally.

The motivation for this approach lies in the view that consumers and businesses are not profiting enough from a heavily globalized and competitive market, where the largest choice of goods and services is curtailed due to different consumer law-related obstacles. This effort to standardize regulatory regimes in order to enhance market access is further supported by the actual policy of consumerism, which prioritizes increased cross-border consumption. On the one hand, businesses seek legal certainty. With regard to their cross-border activities, traders, especially small and medium sized enterprises, face uncertainty as to whether they comply with the applicable rules of consumer law. In that sense, regulatory coherence is of essential importance to facilitate cross-border trade. On the other hand, the challenge of consumer trust is of essential importance, as consumers want to know that they are protected when crossborder shopping, again to facilitate their engagement in the globalized consumer market. Cross-border trade needs to be predictable, and the goal here is to ensure legal certainty for both businesses and consumers as key drivers of a competitive, innovative, and dynamic market.

In the context of this second goal of internationalizing consumer law, the World Trade Organization (WTO) is expected to take a leadership role. However, surprisingly, to this day, the WTO's activity in the area of global consumer protection has been minimal (Durovic and Micklitz 2017, pp. 5-23). Instead, different regional initiatives have pursued the unification of consumer law requirements at regional levels. This is the case with the European Union, Association of Southeast Asian Nations (ASEAN), the Central African Economic and Monetary Community, CARICORUM, and the Common Market for Eastern and Southern Africa (United Nations 2018, p. 12 (Point 52)).

In the preceding discussion, the two goals (introducing an acceptable, international, minimum standard for consumer protection, and standardization of consumer law requirements to facilitate cross-border trade) of the process of internationalization of consumer law were treated as distinct; however, it has to be emphasized that, in reality, these two purposes may overlap. The most obvious example is the case of the European Union. In the case of a majority of the European directives belonging to the body of EU consumer law, their initial objectives have been both the achievement of high levels of consumer protection on a panEuropean level and the strengthening of the Internal Market through the abolition of obstacles to cross-border trade in goods, services and digital content (Recitals (4), (5) and Article 1, Directive 2011/83/EU on consumer rights ("Consumer Rights Directive"); Article 1, Directive 2005/29/EC on unfair commercial practices ("Unfair Commercial Practices Directive")). 


\section{The Importance of the UN Guidelines on Consumer Protection}

\section{A Global Minimum Level of Consumer Protection}

The year 2020 is an important year for international consumer law. This year will mark thirtyfive years since the adoption of the first version of the UN Guidelines for Consumer Protection. ${ }^{7}$ Thirty-five years later, the UN Guidelines still remain the most important global instrument in the area of consumer protection, contributing to building of trust of both consumers and traders acting on the market. Accordingly, the two principal questions are what the contribution of the UN Guidelines to the development of consumer law has been, and how much the UN Guidelines have contributed in practice to the internationalization of consumer law during the thirty-five years of their existence.

Interestingly enough, despite being the most important international document in the area of consumer protection, the UN Guidelines have attracted surprisingly little attention from legal scholars and, generally speaking, any kind of assessment. In practice, very little has been written about these Guidelines. One might argue that this lack of interest might mean that the practical relevance of the UN Guidelines is actually minor, so they do not deserve any assessment.

However, the reason behind this lack of interest in consumer protection probably lies in the fact that, from a comparative perspective, there was never a proper empirical study about the real impact of the UN Guidelines in practice, so their real influence is difficult to assess. However, what is certain is that they have had some impact on the development of consumer laws in the developing countries (Harland 1997). A more precise understanding of their impact on the national consumer laws is still unclear. Likewise, in reality more focus was dedicated to follow other supranational consumer law regimes, such as EU Consumer Law, because these are much more advanced, and have accordingly been used extensively as a model throughout the world (Stuyck and Durovic 2016). It should also be noted that other international organizations besides the UN, such as the Organisation for Economic Co-operation and Development (OECD), World Bank or G20 have also been involved in some of the consumer law developments. ${ }^{8}$ However, the proper global representative character of these organizations is questionable as they seem to be rather exclusive international organizations for economically developed countries. In addition, their activity in consumer protection is neither complete nor horizontal, but rather focused on specific elements of consumer law, such as consumer credit law.

The UN Guidelines, as their names suggests, are only guidelines; as such, they are not, stricto sensu, legally binding. The UN Guidelines are only a soft law, a model that the countries may, but are not legally obliged to, follow. Being soft law, the Guidelines represent an effective way to generate consensus for their adoption among all the UN countries. The effects of non-legally binding instruments are again very questionable.

This is why the UN Guidelines effects in practice are very problematic. Not being binding, the UN Guidelines leave a lot of autonomy to individual countries to design regulatory systems of consumer protection in line with the needs and particularities of their legal systems, as well

\footnotetext{
${ }^{7}$ United Nations General Assembly, Resolution 39/248 of 16 April 1985 (A/RES/70/186). Retrieved from https://www.un.org/documents/ga/res/39/a39r248.htm (accessed 25 June 2019).

8 The OECD, for instance, has set up a Committee on Consumer Policy (CCP) with the aim of both tackling a variety of consumer policy issues and of fostering international cooperation among public authorities. Retrieved from https://www.oecd.org/sti/consumer/ (accessed 25 June 2019). Similarly, the G20 has arranged a Task Force on Financial Consumer Protection in cooperation with the OECD. Retrieved from http://www.oecd. org/finance/financial-education/g20-oecd-task-force-financial-consumer-protection.htm (accessed 25 June 2019).
} 
as their specific economic, social and political contexts. This is doubtlessly a positive phenomenon. However, the development of an effective consumer law at the national level on the basis of the Guidelines (which are rather vague and broad) still remains a challenge. Most importantly, the UN Guidelines do not help much with enforcement, which is an especially important and most problematic field of consumer law.

Some years before the adoption of the first version of the UN Guidelines, the United Nations managed to reach consensus to adopt a binding legal instrument in another area of private law, international commercial contract law. This was the Vienna Convention on International Sales of Goods 1980 (CISG). The CISG does not apply to consumer contracts (Art. 2(a), CISG). Today, the CISG has become one of the most widely available commercial contract law regimes regulating contracts for cross-border sales of goods in the world (Bonell 2008). However, bearing in mind the fact that it is a binding legal instrument, a convention, it has left a number of legal gaps and it has also been impossible to agree to ever modify any of its parts or develop it further (Di Matteo 2013). This is why, to this day, the Convention has remained in its original form, despite the need for some changes and clarifications.

In contrast to the CISG, the soft law character of the UN Guidelines enabled further development, and ensured that the Guidelines could freely address all areas of consumer protection. The UN Guidelines are a kind of a codex of fundamentally recognized consumer rights. In that sense, the soft law character of the Guidelines may be even recognized as its positive characteristic, securing its completeness and also its dynamic character, and capacity to adapt more easily to the changes than in case if it was a binding legal document. Eventually, the Guidelines were used as an inspiration and model for many of the world's countries to develop their national systems of consumer protection on the ground of the fundamental consumer rights listed in the Guidelines (United Nations 2013). Some countries have even incorporated the achievement of a high level of consumer protection into their national Constitutions (Benöhr and Micklitz 2010, pp. 36-38).

The experience with the UN Guidelines demonstrates well that the adoption of a universal Convention or any other kind of binding legal instrument for consumer rights is, at this stage, rather impossible. In this sense, the CISG does not represent a good model for international consumer law, primarily because of different objectives they pursue. International contract law and international consumer law pursue different objectives. Broadly, the goal of international commercial contract law is to provide a set of neutral, uniform rules to govern commercial transactions between businesses. The idea is to regulate transactions in an unbiased manner. For instance, a key aspect of the CISG has been to have an equal level of protection for the buyer and for the seller (Arts. 1-4, CISG). Remedies are also provided, but there is nothing on enforcement, which is in practice done primarily through arbitration, but also through the national courts as there is no supranational court to adjudicate on CISG matters.

Moreover, from a policy perspective, protecting the rights of the contracting parties, buyer and seller, is not seen as of any kind of concern. Conversely, in international consumer law (as well as in national consumer law regimes, of course), the focus always needs to be on protecting consumers as a weaker party in their commercial relationship with traders "as regards both his bargaining power and his level of knowledge", as pointed out by the Court of Justice of the European Union. ${ }^{9}$ One can

\footnotetext{
9 Joined Cases C-240/98 to C-244/98 Océano Grupo Editorial SA v Rocio Murciano Quintero e.a. [2000] ECR I-04941, para 25; Case C-168/05 Elisa María Mostaza Claro v Centro Móvil Milenium SL [2006] ECR I-10421, para 25; Case C-40/08 Asturcom Telecomunicaciones SL v Cristina Rodriguez Nogueira [2009] ECR I-9579, para 29
} 
appreciate, therefore, that, in seeking to redress the imbalance between traders and consumers, international consumer law could not attempt to create a level playing field for both parties in the way that international commercial contract law does. What becomes clear is that international consumer law cannot just transpose the achievements of the CISG for its own agenda - the two disciplines are irreconcilably different in the objectives they pursue.

The strength of the UN Guidelines lies in the fact that they were adopted by the United Nations - the most prominent and representative international organization comprising all internationally recognized countries. A comparison can be made with the UN Declaration of Human Rights, which is only a declaration, but is still respected as a minimum set of human right recognized to every single human being globally (United Nations 1948).

Importantly, the UN Guidelines do not call for a mandatory harmonization of the national consumer laws. On the contrary, the UN Guidelines acknowledge the presence of differences among consumer law regimes throughout the world. One of the reasons behind such an approach might be that it is very difficult to talk about the "consumer" from an international perspective as a homogeneous term. Consumers substantially differ between the many countries of the world, and their needs are materially different. Members of the UN comprise nations in various stages of economic and social development, with different levels of consumer awareness. Access to essential services can be the benchmark, bringing into focus the differences of consumer law objectives in pursuance of a broader goal across the globe: in economically developed states, the focus of consumer law is on the protection of the economic interest of consumers, meanwhile, in emerging economies, the priority for local consumer law ought to be on securing consumer access to water, electricity or other basic needs. The foregoing illustrates the basic goal of consumer law as improving the standard of living of consumers, no matter where they live.

In that sense, it may be observed that the main goal of the UN Guidelines is not to abolish the obstacles to cross-border trade. Rather, they were created to establish minimum benchmarks for consumer protection that should apply to all consumers globally and below which minimal level no UN Member States should ever descend. The UN Guidelines just set up the solid foundations or the ground on which national consumer laws should be further developed in their own idiosyncratic way. The universal character of consumer protection is recognized by the Guidelines in its definition of the consumer, which stresses that the nationality of consumer is irrelevant for its scope of protection. ${ }^{10}$ Moreover, the Guidelines also pay particular attention to the protection of vulnerable and disadvantaged consumers. One of the problems of the globalization is that it aggravates consumer's vulnerability even more as consumers performing cross-border transactions are very difficult to be protected (Goldring 1996).

\section{Modification of the UN Guidelines}

The United Nations General Assembly believed that a robust legal and regulatory framework for consumer protection serves an important public interest, contributes to economic dynamism, and favours consumer welfare. ${ }^{11}$ After their adoption, the UN Guidelines were modified

\footnotetext{
${ }^{10}$ Guideline 3 of the UN Guidelines: "consumer" generally refers to a natural person, regardless of nationality, acting primarily for personal, family or household purposes, while recognizing that Member States may adopt differing definitions to address specific domestic needs.'

${ }^{11}$ UN General Assembly, Resolution 70/186 on Consumer Protection of 22 December 2015. Retrieved from https://unctad.org/meetings/en/SessionalDocuments/ares70d186_en.pdf (accessed 25 June 2019).
} 
twice: in 1999 and in 2015. The first modifications in 1999 made a small but very significant addition $^{12}$ : The UN Guidelines were expanded to include the principle of sustainable consumption as one of the major principles (United Nations 2003, p. 1 (GL 1(h)). That revision of the UN Guidelines had been proposed by Argentina at the Rio Earth Summit. ${ }^{13}$ Despite being promoted by the UN Guidelines more than two decades ago, sustainable consumption as one of the goals of consumer policy has become present only in recent years, such as in attempts to link consumer protection with the circular economy.

In comparison with the 1999 revision, the second revision of the Guidelines in 2015 was much more extensive. These changes were approved on 22 December 2015 by the UN General Assembly. The 2015 modifications reflect a rising interest and increasing relevance of consumer law worldwide. The purpose of the second revision was to adapt the Guidelines to the changes in society, economy, advertising techniques, technology, and the needs of the consumers, and also to prepare the UN Guidelines for future changes. The 2015 amendments recognized the need for more consumer protection globally and paid particular attention to cross-border consumer transactions. Still, the question that remains is what and how is to be achieved.

The reform of the Guidelines has resulted in the inclusion of some of the new fundamental principles of consumer law: e-commerce, financial services, data protection, misleading energy advertising, cross-border trade, transport, access to universal services, access to knowledge, tourism, consumer redress. ${ }^{14}$ It is obvious that the attempt was to address some of the most relevant consumer law topics. For instance, consumer protection in financial services has been of extreme relevance in the context of the global financial crisis of 2008.

The responsiveness of the UN Guidelines to the changing requirements for effective consumer protection, especially after the 2015 revisions, is in part due to the involvement of UNCTAD. Even after its latest modifications, the UN Guidelines still only provide a vague model for national consumer legislation for countries to follow. The UN Guidelines list the most important principles of consumer law, but they cannot simply be copy-pasted into their national legal systems. In that sense, more guidance is missing.

\section{A Set of Best Practices}

The UN Guidelines identify best market practices, which need to be implemented in businessto-consumers transactions. This set of practices proved to be of particular help to emerging economies which either did not have a regime for consumer protection at the time, or only had an underdeveloped regime (Harland 1987). The UN Guidelines start with pointing out to the seven fundamental principles on which the entire consumer law regime has been built: the protection of health and safety of consumers; the protection of economic interests of consumers; the provision of consumers with adequate information; consumer education; accessibility of consumer to an effective means of redress; the establishment of consumer associations

\footnotetext{
${ }^{12}$ United Nations Conference for Trade and Development, United Nations Guidelines for Consumer Protection (as expanded in 1999) A/RES/39/248. Retrieved from http://unctad.org/en/docs/poditcclpm21.en.pdf (accessed 25 June 2019).

${ }^{13}$ UN General Assembly, Decision 54/449.

${ }^{14}$ UN Guidelines, 11(d) ("education and awareness-raising"); 11(e) ("protection of privacy"); 11(f) ("consumer complaints and disputes"); 63-65 ("electronic commerce"); 66-68 ("financial services"); 76 ("energy"); 77 (“public utilities"); 78 ("tourism"); 94 (on “international trade").
} 
and consumer participation in decision making process; and sustainable consumption (United Nations 2016, pp. 7-9 (Part III)).

There is a noticeable similarity between these seven basic principles and the fundamental rights of each consumer outlined by President John F. Kennedy back in 1962 which led to the development of consumer law and policy as a distinct field. The introduction of sustainable consumption represents the recognition by consumer policy of the patterns developed outside of consumer law related to sustainable development and protection of the environment. These developments now play a key role in the evolution of common consumer policy, displaying a tight connection between environmental and consumer protection, aggravated by the consumerism of today's global society.

In addition to defining the fundamental rights that should be attributed to all consumers, the Guidelines provide rules for how these rights should be applied and enforced in practice. The Guidelines pay particular attention to strengthening cross-border cooperation among countries in order to guarantee a high level of consumer protection. It is for this reason that the Guidelines identify the principles on which international cooperation among states should be founded. The latest amendments to the UN Guidelines in 2015 have again emphasized this need for international cooperation.

The revised UN Guidelines pay particular attention to the development of international cooperation among the countries and sharing of experiences in consumer protection (United Nations 2016, pp. 25-29 (GLs 79 et seq.)). However, what is missing in the Guidelines is how to establish that cooperation. The UNCTAD Implementation Report adopted in 2013, as part of the process of expansion of the UN Guidelines, points to the need to establish and enforce international standards, including neutral networks. Eventually, the enhancement of the international cooperation in the area of consumer protection has been emphasized as one of the major improvements of the UN Guidelines in 2015 (United Nations 2016, p. 6 (GL 1)).

Globalization, followed by the development of the borderless nature of the increasingly present digital economy, and the proliferation of consumer law regimes have led to a significant increase in the complexity of cross-border consumer law enforcement cooperation.

The UN Guidelines demonstrate that the focus should be on cooperation, if it is accepted that international consumer law is meant to establish a global minimum level of consumer protection. Cooperation is imperative to enable international consumer law to establish protection of consumers, but will also benefit businesses, as consumer gain confidence to engage on the cross-border market, driving up sales and profits to the traders. Conversely, convergence is more necessary from the perspective of the developing of international consumer law as a means to overcome cross-border differences and enhance cross-border trade. For fostering cooperation in the area of consumer protection on a global level, the networks established with that purpose are especially important, the most important of which is undoubtedly ICPEN. And cooperation is the most needed in the area of enforcement of consumer law. In that sense, the existence of cooperation aimed to secure a minimum level of consumer protection seems to be a better policy option from the perspective of boosting consumer confidence than the substantive harmonization of consumer law which does not necessarily lead to a more confident consumer (Wilhelmsson 2004).

\section{The Role of UNCTAD}

The United Nations have designated a special body to deal with the Guidelines together with some other market-related regulations (e.g., competition law) - the United Nations Conference 
for Trade and Development (UNCTAD). UNCTAD's main objectives are, first, to provide a forum for intergovernmental deliberations, second, to undertake research, policy analysis and data collection to inform such deliberations, and, eventually, to provide technical assistance to developing countries. ${ }^{15}$

Accordingly, it was UNCTAD that was in charge of the revision of Guidelines in 2015 (United Nations 2013). As of their engagement in the revision of the UN Guidelines, UNCTAD has shown a growing interest in addressing consumer law challenges and confirming that UN is dedicated to play a more active role in the internationalization of consumer law. Subsequently, UNCTAD invested significant efforts in the promotion of the Guidelines and their application in practice, as well as contributing to consumer protection in general. UNCTAD is engaged in a number of consumer protection-related technical assistance initiatives in countries with emerging economies. For instance, UCTAD has been running a kind of fitness check, i.e. the voluntary peer reviews of national consumer law regimes in several countries throughout the world - something that has been recently, for example, performed in case of the Indonesian consumer law (United Nations 2019).

Accordingly, the competences of UNCTAD include its role to work as a laboratory of ideas and provision of on-the-ground assistance to help developing countries raise living standards through trade, investment, finance, and technology; to help developing countries benefit from the globalized economy; and to contribute to the international debate on emerging issues related to developing countries and the world economy.

UNCTAD has also developed a Manual on Consumer Protection (2017). The main objective of the Manual on Consumer Protection is to support emerging economies and economies-in-transition in their choice of consumer policies. Moreover, the Manual is designed to provide practical tools to assist policy makers in enhancing capacities while implementing the UN Guidelines.

Concurrently, the UN has been working on producing the World Consumer Protection Map, ${ }^{16}$ which maps out countries which have a designated consumer protection regime. This is a visual representation of national approaches to consumer protection worldwide. The UNCTAD map shows that, on a global level, $52 \%$ of countries have consumer law, $6 \%$ of the countries have drafts of consumer laws, whereas $10 \%$ of countries have no legislation on consumer law whatever. For the remaining $32 \%$ of countries, there is no available data, which does not necessarily mean that they do not have any consumer protection legislation, but simply that the relevant information is missing. The region with particularly low level of presence of consumer legislation is Africa, ${ }^{17}$ where additional efforts need to be invested to protect consumers. $^{18}$

Apart from the adoption of the UN Guidelines, one of the most important outcomes of UNCTAD's efforts is the establishment of an intergovernmental group of experts on consumer protection law and policy under its own auspices as a permanent group which has its regular

\footnotetext{
${ }^{15}$ UNCTAD, Competition and Consumer Policies Programme. Retrieved from https://unctad. org/en/Pages/DITC/CompetitionLaw/ccpb-Mandate.aspx(accessed 25 June 2019).

${ }^{16}$ UNCTAD (2019), World Consumer Map. Retrieved from https://unctadwcpm.org/map.html (accessed 25 June 2019).

${ }^{17}$ See: Special Issue of the Journal of Consumer Policy on Consumer Law and Policy in Africa (Vol. 41(4), December 2018).

${ }^{18}$ Retrieved from https://unctad.org/en/Pages/DTL/STI_and_ICTs/ICT4D-Legislation/eCom-ConsumerProtection-Laws.aspx(accessed 25 June 2019).
} 
meetings. ${ }^{19}$ The first meeting took place in October 2016. After its second meeting in July 2017, the participants identified some of the major problems that consumers are faced with on the global online marketplace. The Group has confirmed that taking swift action is of essential importance. This is why UNCTAD created a new working group dedicated to ecommerce, which aims to identify and propose solutions to consumer problems in that area.

Some of the roles of the intergovernmental group include monitoring the implementation of the UN Guidelines, but its summits are also to be used as a forum for exchange of best practices and technical cooperation and capacity building in the area of consumer protection. The internationalization of consumer protection law is particularly important for the developing countries and economies-in-transition. The inter-governmental group may also be considered as a compromise solution to the old proposal of foundation of a new and separate UN Commission as the main international institution in charge of consumer protection. The idea of establishing a UN body, akin to the World Consumer Organisation, has been present since the mid-1980s, but it has never been implemented in practice due to the continuing lack of required political support up to the present day. The real impact of the inter-governmental group remains to be seen. As matters stand now, its meetings have been held on a regular basis. A particularly interesting and important question is whether the existence and work of the inter-governmental group will set up the foundations of the international governance in the area of consumer protection or will just remain an open forum for discussion of diverse global consumer law problems (Izaguerri 2019).

\section{The Role of ICPEN}

\section{International Cooperation in the Area of Enforcement of Consumer Law}

Securing the effective and efficient enforcement mechanism which will enable adequate protection of consumer's rights is the major challenge of consumer policy. That challenge becomes even more present in situation of cross-border consumer transactions (Rickett and Telfer 2003). This is why in the case of international consumer law and policy, there needs to be a strong focus on consumer enforcement and how to address consumer problems with a cross-border element. However, as it stands now, there is no single organization in charge of enforcement of consumer law on a global level (Lima Marques and Wei 2017). Likewise, there are no proper international consumer dispute resolution schemes. Enforcement is limited to different forums and networks, most of which are limited to specific regions.

Out of these networks, the most advanced one is certainly the one of the European Union established initially by Regulation (EC) 2006/2004 and recently reaffirmed by the Regulation (EU) 2017/2394 on cooperation of consumer protection authorities. The European mechanism requires national agencies to have common investigative and enforcement powers, to share information, and to have the power to seek and obtain action from their counterparts in other EU Member States.

Among the existing structures and networks dealing with enforcement of consumer law on a global level, the International Consumer Protection and Enforcement Network (ICPEN) is today the sole international body dedicated wholly to the global aspects of consumer law enforcement. It represents a true global network of the authorities in charge of enforcement of

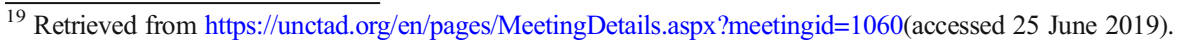


consumer law throughout the world. ICPEN is an excellent example of an informal way to establish a pathway for cooperation among consumer protection authorities and a forum for a multi-stakeholder dialogue. The predecessor of ICPEN was the International Marketing Supervision Network (IMSN) which was in 2002 renamed ICPEN in order to better reflect the objective of the network (ICPEN 2016, p. 2 (Point 3)).

ICPEN is a network of consumer law authorities comprising representatives of more than 60 countries and international organizations involved in consumer law issues. The number of countries participating in this network is rising. UNCTAD is also an active observer organization of ICPEN. The leadership of the organization is modelled on the presidency-rotation principle, whereby the presidency rotates between members on an annual basis. This structure ensures that there is an appropriate geographical representation and participation of all of its members. The ICPEN presidency is supported by an advisory group.

ICPEN includes some of the major global consumer markets such as the USA, Australia, Japan, the UK, or Canada. However, the network is still rather fragmented. For example, only roughly half of the competent authorities of the 28 EU Member States are part of the network. Therefore, despite its increasing number, still only fewer than one-third of countries are involved in the network, which substantially questions its real global character. Further efforts are needed in order to transform ICPEN into a proper global enforcement network. However, ICPEN may contribute to the development of uniformity of consumer protection on a global level without the need for the harmonization of the consumer law rules.

The existence of ICPEN may potentially be very important for the international protection of consumers as it secures a collaborative forum for developing and maintaining regular contact between consumer protection agencies, enabling them to learn from each other's experiences and draw on each other's practices. ICPEN ensures a global identification, target, and response of the cross-border consumer law issues faced by consumers performing transactions on the global digital market.

However, due to its nature, ICPEN competences and activities are of a rather limited character which limits its role in practice. As it stands now, the main format of ICPEN activities involves the organization of the annual meetings and best practices workshops. One of its achievements has been the development of a system for the exchange of information and assistance among different national agencies (ICPEN 2016). Likewise, ICPEN organizes education campaigns. For example, that is the case with ICPEN's organization of the Fraud Prevention Month. ${ }^{20}$ In that sense, ICPEN represents an excellent starting point for the global forum for cooperation in the area of consumer law. However, in order to enhance its relevance in practice, its competencies and activities need to be broadened further in the future.

\section{The Role of ICPEN}

The main aim of ICPEN is to encourage practical action against cross-border-marketing misconduct by traders. Six long-term goals have been identified to achieve this main objective. These include first, the collection and exchange of information in topics relevant to consumer protection; second, the sharing of best practices related to legislative and enforcement elements of consumer protection; third, the undertaking of actions to combat cross-border breaches of consumer legislation; fourth, the facilitation of effective cross-border remedies; fifth, the detection and promotion of effective means for the enforcement of consumer law, and, sixth,

${ }^{20}$ Retrieved from https://www.icpen.org/initiatives (accessed 25 June 2019). 
the endorsement and development of wider participation and cooperation with other bodies responsible for the enforcement of consumer protection rules (ICPEN 2016, p. 2 (Point 4)).

Two prevailing instruments can be identified for the achievement of these goals: the sweep actions and the development of the internet platform of www.econsumer.gov. Sweep actions performed by ICPEN identify suspicious websites to be used to prosecute the traders behind such websites by the relevant national authority or for education purposes. ICPEN International Internet Sweeps is a global initiative of national consumer agencies with the aim of protecting and securing the confidence of consumers in e-commerce. ${ }^{21}$

Some of the members of the ICPEN network performed a coordinated sweep action in February 2018, the objective of which was to check standard terms and conditions of hundreds of traders that operate locally, regionally and globally in a number of industry sectors. ${ }^{22} \mathrm{~A}$ number of problems with the terms and conditions had been identified, such as their length, lack of transparency, and clarity, making them difficult to understand for consumers. The result was the launch of the ICPEN campaign. In 2019, ICPEN wrote to two major players on the digital market, Apple and Google, requiring them to provide clear and comprehensive information about how apps in their stores collect and use consumer data. ${ }^{23}$ Such sweep actions also exist at the regional level, such as Europe, where "EU-Sweeps" have been developed. ${ }^{24}$ EU-Sweeps primarily refer to the identification of online breaches of consumer law which require simultaneous and coordinated action. Sweep actions are a good starting point that need to be developed further.

\section{The Online Database}

Besides the International Internet Sweeps, ICPEN has also developed the www.econsumer.gov website. ${ }^{25}$ This website enables the easy reporting of the international scams online. ICPEN's focus seems to be on the digital economy. ICPEN's action encourages businesses participating in the digital market to review their standard contractual terms and conditions and marketing practices to ensure compliance and respect for consumer rights. ${ }^{26}$ ICPEN may play a very important role in consumer protection as it provides this international dimension and also enables the exchange of information. The sharing of information is especially important in the modern, data-driven economy as the presence of a global data flow is an international legal problem not only for consumers.

The website www.econsumer.gov enables consumers to submit complaints relating to cross-border transactions online, and to become familiar with the alternative dispute resolution mechanisms available against foreign traders. The platform is available in seven languages, and consumers who consider themselves victims of unfair practices can use the website to submit their claim. However, seven languages for a global initiative seem to be insufficient. The development of modern technologies facilitates translation and that is something that

\footnotetext{
21 Ibid.

22 Retrieved from https://www.icpen.org/news/902 (accessed 25 June 2019).

${ }^{23}$ Retrieved from https://www.uokik.gov.pl/news.php?news_id=15329 (accessed 25 June 2019).

${ }^{24}$ Retrieved from https://ec.europa.eu/info/live-work-travel-eu/consumers/enforcement-consumerprotection/sweeps_en25 (accessed 25 June 2019).

${ }^{25}$ Retrieved from https://www.icpen.org/initiatives (accessed 25 June 2019).

${ }^{26}$ Retrieved from: https:/www.icpen.org/sites/default/files/2018- 06/ICPEN\%20Joint\%20Letter\%20on\%20 Terms\%20and\%20Conditions.pdf (accessed 25 June 2019).
} 
ICPEN should profit from in order to improve the database accessibility to everyone irrespectively of the language knowledge.

The submitted complaints help consumer protection authorities conduct their investigations and to act to prevent further scams. Consumers need to be aware of the existence of this system as the lack of consumer and business awareness might endanger its application in practice. Moreover, for the application of platforms, strict guarantees of confidentiality and data protection need to be strictly respected as this is a necessary pre-condition for using of any of the online platforms for resolving of consumer disputes. The website www.econsumer.gov is dedicated to protecting the confidentiality of all of the data collected and none of the aggregated information will contain any of the personal identifying information of the person who has submitted a complaint. ${ }^{27}$

Consumers are always advised first to attempt to resolve the problem directly with the trader. National consumer agencies have access to the platform in order to monitor online conduct, and to take adequate enforcement actions where necessary. An example of the success of the www.econsumer.gov mechanism in practice is the closure of the Designer Brand Outlet, which was offering counterfeit designer clothing, by the Australian Competition and Consumer Commission. ${ }^{28}$ This was the outcome of the complaints of foreign consumers, which resulted in a joint action by several global consumer agencies. In line with the increasing popularity of Alternative Dispute Regulation (ADR) mechanisms as an effective means of resolving consumer disputes, ICPEN also promotes alternative means of resolution. For this purpose, ICPEN provides a directory of the ADR bodies in all of the participating countries. ${ }^{29}$

ICPEN has a key role to play in promoting the further development of the cross-border enforcement of consumer rights through the adoption of its "name-and-shame" approach, underpinning the application of the www.econsumer.gov database. To adequately perform that role however, ICPEN's network and powers must be expanded. The www.econsumer.gov website deals with consumer complaints regarding cross-border transactions, but it is limited to scams operated by traders and does not resolve individual cases. It merely enables the competent authorities to spot trader tendencies that breach consumer law and to combat fraud against consumers.

It is interesting to observe the statistics of complaints submitted through the ICPEN. The latest www.econsumer.gov report for the calendar year 2018 shows that, by far, most complaints come from consumers based in the USA (13 107) which is then followed by the consumers based in France $(2,201)$, India $(1,573)$, Australia $(1,305)$, and the UK $(1,156)$ who have all together made fewer complaints than American consumers. ${ }^{30}$ Comparing the numbers for 2018 with those for 2017, a steep rise in the number of complaints submitted is noticeable, which is a positive sign of increasing consumer awareness of the redress offered by the ICPEN website. When it comes to the companies against whom complaints were filed, a huge majority of them were based in two countries, namely China $(5,440)$ and the USA $(5,435)$. This is then

\footnotetext{
${ }^{27}$ E.consumer.gov (2018). How we use and share your data. Retrieved from https://econsumer. gov/Overview\#crnt (accessed 5 October 2019).

${ }^{28}$ Australian Competition and Consumer Commission. (2018). 'Designer brand outlet' website suspended. Retrieved from https://www.accc.gov.au/media-release/designer-brand-outlet-website-suspended (accessed 25 June 2019).

${ }^{29}$ E.consumer.gov (2018). Directory. Retrieved from http://www.econsumer.gov/english/resolve/directory-ofadrs.shtm (accessed 25 June 2019).

${ }^{30}$ E.consumer.gov (2018). Top consumer and company locations: January 1 - December 31, 2018. Retrieved from https://econsumer.gov/en/ComplaintTrend\#crnt (accessed 25 June 2019).
} 
followed by a significantly lower number of complaints against companies based in the UK $(2,354)$, India (1,335), and Japan (786). ${ }^{31}$ Still, despite the increasing number of submitted complaints, bearing in mind how much people are moving, the existence of billions of consumers in the World that are increasingly performing cross-border transactions, it is obvious that there should be much more complaints shown. In that sense, further education of consumers about the existence of this website and how it is to be used is certainly needed.

\section{The Contemporary Challenges of International Consumer Law}

The development of international consumer law, in particular the UN Guidelines and ICPEN's effort, needs to take into consideration the contemporary challenges that consumer policy is faced with. Today, consumer law and policy is faced with two major challenges, which need to be addressed adequately on the global scale. The first one is an increasing number of crossborder transactions, whereas the second one is the rise of Internet as the leading global marketplace and the entire technological developments which have disrupted the traditional consumer law.

These two challenges are not necessarily wholly separate. On the contrary, they seem to be, to a large extent, tightly connected, and hence require to be addressed jointly. This is because it is precisely the rise of Internet as a global marketplace that has substantially contributed to the increase of cross-border trade, as it does not require the physical movement of the counterparties to the transactions. As a consequence of its world-wide nature, the Internet has allowed a massive increase in the number of consumer transactions where the trader and the consumer are located in different legal jurisdictions, let alone on two different continents. On the other hand, the Internet can be easily employed as a global place for resolution of consumer disputes as it was initiated by the ICPEN and its website www.econsumer.gov.

The Fourth Industrial Revolution is characterized by a rapid change of the marketplace and the increasing relevance of the new technologies (Li et al. 2017). The development of new technologies has opened up new possibilities for consumers and businesses, but has also brought particular challenges to consumer law and policy. An excellent example is the increasing relevance of online platforms and global companies such as Uber, which have significantly affected traditional consumer law (Hatzopoulos 2018). New technologies are characterized by a certain level of complexity caused by the number of intervening actors, the interdependency between devices, the autonomous actions of products, the collection, analysis and use of significant amount of data and the possibilities of extensions and updates of products already placed in the circulation (European Commission 2018).

Today, international consumer law is faced with the task of responding to these changes and providing the right regulatory environment. However, the one important caveat is that consumer law is not supposed to stymie the developments of new technologies and their application in practice. On the contrary, consumer law needs to ensure that the technological developments do not result in diminution of the level of consumer protection, i.e., a certain level of consumer protection has to be kept irrespectively of the technological development or progress. The underlying thread is consumer trust - consumer law ought to maintain a sufficient level of consumer trust in the market (by maintaining the minimum threshold) to promote cross-border online trade, while remaining proportionate and sufficiently flexible to accommodate future innovation.

31 Ibid. 
However, it is true that digital technologies have brought many benefits to consumers, including new products and services. At the same time, these technologies have also brought some new consumer law challenges. For example, the technology enables manipulation of the digital fora that provide reviews of products and services, or retaliation against or monitoring of consumers who criticize traders in online reviews. Furthermore, the application of smart contracts in business-to-consumers transactions has opened a few important legal questions particularly because smart contracts are self-enforcing. Their self-enforcing nature poses the question of how to adequately protect consumers in such a dynamic environment (Borgogno 2018).

In the contemporary world, data issues have become a substantial part of consumer services, such as services offered and provided in the financial, health, and retail industries. The new technologies have also increased the likelihood of a global mass harm of consumers in all parts of the world. An excellent example is the recent Facebook scandal. On the positive side, the development of new technologies may be beneficial for the consumer protection goals, especially in the case of cross-border transactions. That can be best seen in the case of the development of special online mechanisms for resolution of consumer disputes (Cortés 2018). Furthermore, the application of new technologies can be helpful in situations where consumer problems are straightforward, i.e., consumer seeking compensation in case of delayed or cancelled flights and breach of consumer's right established by the applicable legislation (Regulation (EU) No. 261/ 2004).

In the era of such quick technological challenges, international consumer law and policy should be focused on securing adequate level of consumer protection on a global level. Beside goods and services, the digital content and digital services have become a third form of consumer product. One unresolved question is how the proliferation of new technology could aid the enforcement of consumer law, a question on which the practice of smart contracts offers valuable insights. In that context, an application of the new technology can be found in the development of special software designed to check standards terms and conditions of consumer contracts and their compliance with consumer protection laws (Micklitz et al. 2017).

\section{Conclusions}

All in all, it may be concluded that the UN Guidelines and ICPEN are certainly great ideas and provide solid foundations of the international consumer law. However, further efforts are needed to create a more complete and a more efficient system of international consumer law. As it stands now, an establishment of a uniform, unified, and harmoniously applied global consumer law with a centralized dispute resolution system seems to be an impossible mission. The focus of the international consumer law should not be on development of unified substantive rules on consumer protection, but on the securement of adequate enforcement of consumer law. That is the most problematic and the most important element of consumer law. In that sense, UNCTAD, as the focal point within the United Nations on consumer protection, might contribute to the improvement of enforcement of consumer law on a global level. In that sense, what should be further strengthen is the UNTAD's role in facilitating the coordination of efforts at the national, regional and international levels (United Nations 2018, p. 12).

International consumer law needs to pay particular attention to providing an adequate regulatory response to the developments of new technologies and the rise of Internet as a global marketplace, but also to profit from these developments. These developments may 
facilitate infrastructure for communication and cooperation in the area of consumer law, in particular in the area of enforcement of consumer law where a cross border dimension is present. What seems to be the biggest challenge for the international consumer law is how to secure an adequate and efficient legal framework for such a cooperation in the future. There should be a global consensus among the nations to work on this issue and this is where further efforts need to be invested in.

ICPEN certainly represents a good starting point, but its further development is certainly indispensable. For example, the existing ICPEN network could be also used to develop a global database on how a consumer law problem is to be resolved under different consumer law jurisdictions that consumers could easily consult if they have any kind of consumer law related problem. It is true that language differences might be a problem, shifting the focus on translation. However, this is yet another area where new technologies may secure an automatic conversion between languages to provide consumers with a basic explanation of the key provisions of the substantive national consumer law legislation and case law.

Open Access This article is distributed under the terms of the Creative Commons Attribution 4.0 International License (http://creativecommons.org/licenses/by/4.0/), which permits unrestricted use, distribution, and reproduction in any medium, provided you give appropriate credit to the original author(s) and the source, provide a link to the Creative Commons license, and indicate if changes were made.

\section{References}

Benöhr, I., \& Micklitz, H.-W. (2010). Consumer protection and human rights. In G. Howells, I. Ramsay, \& T. Wilhelmsson (Eds.), Handbook of research on international consumer law (pp. 16-34). Cheltenham: Edward Elgar.

Bonell, M. J. (2008). The CISG, European contract law and the development of world contract law. The American Journal of Comparative Law, 56(1), 1-28.

Borgogno, O. (2018). Smart contracts as the (new) power of the powerless? The stakes for consumers. European Review of Private Law, 26(6), 885-902.

Cortés, P. (2018). The law of consumer redress in an evolving digital market: upgrading from alternative to online dispute resolution. New York, NY: Cambridge University Press.

Di Matteo, L. A. (2013). CISG as basis of a comprehensive international sales law. Villanova Law Review, 58(4), 691-722.

Durovic, M., \& Micklitz, H.-W. (2017). The internationalisation of consumer law: A game changer. London: Springer.

European Commission. (2018). Liability for emerging digital technologies. Staff-working document (SWD) 137 final 4.

Goldring, J. (1996). Consumer protection, the nation-state, law, globalisation and democracy. Journal of Computer-Mediated Communication, 2(2).

Grainger, A. (2011). Trade facilitation: A conceptual review. Journal of World Trade, 45(1), 39-62.

Harland, D. (1987). The United Nations guidelines for consumer protection. Journal of Consumer Policy, 10(3), 245-266.

Harland, D. (1997). The United Nations guidelines for consumer policy: Their impact in the first decade. In I. Ramsay (Ed.), Consumer law in the global economy: National and international dimensions. Aldershot: Ashgate.

Hatzopoulos, V. (2018). The collaborative economy and EU law. Oxford: Hart Publishing.

ICPEN. (2016). Memorandum on the establishment and operation of the international consumer protection and enforcement network. Retrieved from https:/www.icpen.org/sites/default/files/2017-08/Memorandum_on_ the_Establishment_and_Operation_of_ICPEN_2016.pdf. (accessed 3 December 2019).

Izaguerri, A. (2019). International consumer protection at the United Nations: Towards global governance? Journal of Consumer Policy (forthcoming, published online 30 August 2019).

Li, G., Hou, Y., \& Wu, A. (2017). Fourth Industrial Revolution: Technological drivers, impacts and coping methods. Chinese Geographical Science, 27(4), 626-637. 
Lima Marques, C., \& Wei, D. (Eds.). (2017). Consumer law and socioeconomic development: National and international dimensions. Cham: Springer.

Micklitz, H.-W., Palka, P., \& Panagis, Y. (2017). The empire strikes back: Digital control of unfair terms of online service. Journal of Consumer Policy, 40(3), 367-388.

Ramsay, I. (2006). Consumer law, regulatory capitalism and the 'new learning' in regulation. Sydney Law Review, 28(1), 9-35.

Ramsay, I. (2007). Consumer law and policy: Text and materials on regulating consumer markets (3rd ed.). Oxford: Hart Publishing.

Rickett, C., \& Telfer, T. (Eds.). (2003). International perspectives on consumers' access to justice. Cambridge: Cambridge University Press.

Stuyck, J. (2000). European consumer law after the treaty of Amsterdam: Consumer policy in or beyond the internal market? Common Market Law Review, 37(2), 367-400.

Stuyck, J., \& Durovic, M. (2016). The external dimension of EU consumer law. In M. Cremona \& H.-W. Micklitz (Eds.), The external dimension of EU private law. Oxford: Oxford University press.

Twigg-Flesner, C., \& Micklitz, H.-W. (2010). Think global - towards international consumer law. Journal of Consumer Policy, 33(3), 201-207.

United Nations. (2003). United Nations Guidelines for Consumer Protection (as expanded in 1999). (E/1999/ INF/2/Add.2). New York, NY: Department of Economic and Social Affairs. Retrieved from https://sustainabledevelopment.un.org/content/documents/consumption_en.pdf. (accessed 3 December 2019).

United Nations. (2013). Implementation report on the United Nations Guidelines on Consumer Protection (1985-2013). (E/1999/INF/2/Add.2). Geneva: United Nations Conference on Trade and Development. Retrieved from http://unctad.org/meetings/en/SessionalDocuments/ciclpd23_en.pdf. (accessed 25 June 2019).

United Nations. (2016). United Nations guidelines for consumer protection. (UNCTAD/DITC/CPLP/MISC/ 2016/1). New York, NY: United Nations Conference on Trade and Development. Retrieved from https:/unctad.org/en/PublicationsLibrary/ditccplpmisc2016d1_en.pdf. (accessed 25 June 2019).

United Nations. (2017). Manual on consumer protection. (UNC̄TAD/DITC/CPLP/2017/1). Geneva: United Nation Conference on Trade and Development. Retrieved from https://unctad. org/en/pages/PublicationWebflyer.aspx?publicationid=1998. (accessed 25 June 2019).

United Nations. (2018) Report of the Intergovernmental Group of Experts on Consumer Protection Law and Policy on its third session. (TD/B/C.I/CPLP/15). Geneva: United Nation Conference on Trade and Development. Retrieved from https://unctad.org/meetings/en/SessionalDocuments/cicplpd15_en.pdf. (accessed 25 June 2019).

United Nations. (2019). Voluntary peer review of consumer protection law and policy in Indonesia. (UNCTAD/ DITC/CPLP/2019/1). Geneva: United Nation Conference on Trade and Development. Retrieved from https://unctad.org/en/PublicationsLibrary/ditccplp2019d1_en.pdf. (accessed 25 June 2019).

Wilhelmsson, T. (2004). The abuse of the "Confident Consumer" as a justification for EC Consumer Law. Journal of Consumer Policy, 27(3), 317-337.

\section{Legislation}

\section{European Union}

Directive 2005/29/EC concerning unfair business-to-consumer commercial practices in the internal market (2005) OJ L 149/22

Directive 2011/83/EU on consumer rights (2011) OJ L, 304/64

Regulation (EC) No 2004/261 establishing common rules on compensation and assistance to passengers in the event of denied boarding and of cancellation or long delay of flights (2004) OJ L 46/1

Regulation (EC) No 2006/2004 on cooperation between national authorities responsible for the enforcement of consumer protection laws (2006) OJ L 364/1

Regulation (EU) 2017/2394 on cooperation between national authorities responsible for the enforcement of consumer protection laws and repealing Regulation (EC) No 2006/2004 (2017) OJ L, 345/1

\section{United Nations}

United Nations. (1948). Universal Declaration of Human Rights. (217 [III] A). Paris:

United Nations General Assembly. Retrieved from https://www.un.org/en/universaldeclaration-human-rights/ (accessed 3 December 2019). 
United Nations. (1980). Convention on Contracts for the International Sale of Goods (CISG). New York, NY: United Nations Commission on International Trade Law. Retrieved from https://www.uncitral. org/pdf/english/texts/sales/cisg/V1056997-CISG-ebook.pdf (accessed 3 December 2019).

Publisher's Note Springer Nature remains neutral with regard to jurisdictional claims in published maps and institutional affiliations. 